5-1994

\title{
The Body of the Text: Literacy's Corporeal Constant
}

Carolyn Marvin

University of Pennsylvania, cmarvin@asc.upenn.edu

Follow this and additional works at: https://repository.upenn.edu/asc_papers

Part of the Communication Commons

\section{Recommended Citation}

Marvin, C. (1994). The Body of the Text: Literacy's Corporeal Constant. Quarterly Journal of Speech, 80 (2), 129-149. https://doi.org/ $10.1080 / 00335639409384064$ 


\section{The Body of the Text: Literacy's Corporeal Constant}

\section{Disciplines}

Communication | Social and Behavioral Sciences 


\title{
THE BODY OF THE TEXT: LITERACY'S CORPOREAL CONSTANT
}

\author{
Carolyn Marvin
}

People want to know why I do this, why I write such gross stuff. I like to tell them I have the heart of a small boy-and I keep it in a jar on my desk.

Robert Bloch, author of Psycho ${ }^{1}$

POPULAR and specialist notions of literacy alike conceive of the human body as physically and socially detached from literate practice. Though literacy cannot be taught or practiced without bodies, bodies have rarely been considered as a relevant dimension of literacy theory. ${ }^{2}$ That bodies are thought to be irrelevant to literacy, or capable of corrupting it, is a useful fiction. In fact, bodies are displayed or concealed at different levels in literate practice to accomplish social work, namely, to locate their owners in a social and moral order. A mark of literate competence is skill in disguising or erasing the contribution of one's own body to the process of textual production and practice. A mark of literate power is the freedom to command other bodies for textual display or concealment, as the occasion warrants. In this paper we will use the term embodied literacy to refer to the set of bodily routines associated with text in the service of social stratification. We shall suggest the conceptual relevance of embodied literacy to a discourse of social and cultural borders played out in the unusual avocation of some late nineteenth- and early twentieth-century collectors for acquiring fine books bound in human skin. Our examination of this practice is intended as a contribution to a theoretics of the body in literacy. Literacy we conceive to be a set of variable and culturally specific techniques for organizing, expressing, and performing social relationships around the interaction of texts and bodies.

For some time the body has been the focus of a paradigm in which it is both a classifying social metaphor and a locus of social action where struggles for domination are played out. These two views of the body, as representation and agent, have been articulated by a number of writers including Norbert Elias, Michel Foucault, Mary Douglas, James Clifford, George E. Marcus, Francis Barker, and Bryan Turner. ${ }^{3}$ Insofar as bodies are permanently deposited in social processes, they must be dealt with and managed in literate practice as in all others. The body filtered through literacy and positioned in terms of it is a social sorting device, part of a system for creating, perpetrating, and justifying the allocation of honor, purity, and power as social resources.

Though the body has not been theorized as an element of literate practice, important suggestions about its relation to text are contained in recent scholarly work about die contribution of the repressed but persistently re-emergent body to the formation of a sensibility described as modern or bourgeois. Much of this work focuses on the history of art and medicine, sites, respectively, of elite expression about bodies and elite acts upon them. 
Notable in this regard is Michael Fried's analysis of both Thomas Eakins's painting of The Clinic of Samuel Gross as an allegory comparing surgery and painting, and of Stephen Crane's fiction as a self-reflexive allegory about the author as a corporeal agent in the production of his own writing. ${ }^{4}$ The work of Francis Barker comes closest to the thesis presented here. ${ }^{5}$ His discussion of Rembrandt's painting The Anatomy Lesson of Dr. Nicolaas Tulp as emblematic of a social reorganization of the body argues that emerging seventeenth-century textual practices substituted a self-disciplined, private subjectivity for the subjected specular body of a precapitalist era. Barker's thesis may be too sweeping, for textualized structures of authority and coercion are unstable and imperiled by the body in any era. The body is an unavoidable, rebellious element not only of bourgeois, but every other socially organized life. If text is a characteristic bourgeois device to manage and control bodies, it has rarely been a triumphant one. The textualized body is less divided or eliminated, as Barker suggests, than it is concealed. Nor does self-discipline exhaust the range of controls visited upon bodies in a textualized world. It is not so much that bourgeois bodies disappear, as that the pattern of their textual concealment and display reveals gradations and contrasts in the power of some bodies with respect to others.

The absence of the body as a topic for examination by contemporary theories of literacy suggests the larger invisibility of the body within academic thought and practice, which are highly identified with literate modes. Why is it that academicians are typified as ascetics, contemptuous of bodies or not in control of their own? As Mary Louise Pratt has put it, commenting on the professional code with which anthropologists ritually devalue autobiographical accounts that testify to the unique bodily presence of the ethnographer in a field setting, while elevating the abstracted, detached formal ethnographies that constitute professional capital: "How, one asks constantly, could such interesting people doing such interesting things produce such dull books? What did they have to do to themselves?" 6

\section{DEFINITIONS OF LITERACY: MISSING PARTS}

A theoretics of the body in literacy requires some elemental and preliminary assertions about bodily practice and performance in relation to notions about literate competence and power. The first is that all bodies are disciplined with respect to literacy. Some are disciplined by using it, and some are disciplined to keep away from it. Social distinctions based in literate practice have long been used to identify and equip, or disequip, those who must use up and expend their bodies in physical work, and those with the relative discretion to preserve and protect the physical body from labor and hardship. Fictional, biographical, pedagogical, and other socializing accounts of literacy suggest a stratifying mechanism in which those with access to powerful literate currencies learn to conceal their bodies in the production and manipulation of literate signs through costly strategems of self-control. As a result, the preserved body is less socially visible in the practices and products of literacy than the more visible but less socially esteemed body of illiteracy. For example, the body associated with literacy is not soiled and does not disport itself in conditions in which it can easily become soiled. It wears a clean white 
collar. The body of illiteracy wears a blue collar that may become soiled and makes its presence known by producing an odor of sweat and toil. This mechanism of display and concealment constitutes a principal organizing dynamic for an examination of the socially stratified body in literacy.

As long as literate skills were considered exclusively from a cognitive or mentalistic perspective, oral expression and practice, which are more visibly attached to the body, could be set aside as a distinct and historically prior stage of intellectual development. Cultures could be characterized as literate or oral. The key distinction lay in the claim that literate "thought" is abstract and generalizing, which is to say, disembodied, compared to the concrete and particular "thought" of the embodied voice. Recent reconceptualizations of literacy as a dimension of culture rather than cognition have refocused the traditional bright-line distinction between orality and literacy, since oral practices are inseparably bound up with textual ones, and the division of labor between them is shifting and complex. ${ }^{7}$ To take the simplest example, it is impossible to teach children to read without engaging their bodies, that is, without talking to them. Efforts to eliminate evidence of the body's contribution to textual production are efforts to minimize the visibility of the body in literate practice and to reject certain classes of socially despised bodies. As a kind of negative ideal of what literacy is not, orality has been, and continues to be, the sign of women, children, people of color, primitives, criminals, and other marginalized groups to whom less control over bodily impulses has been ascribed and by extension, less literate competence. ${ }^{8}$

An important hallmark of systems of literate control is the confinement of the body in pursuit of scriptive status and power. In the economy of signs that regulates the relationship between body and text, the body is depicted as struggling against text. Those who are literate struggle with their own bodies, or with the bodies of those whose illiteracy is taken as a sign that they are in need of control. In this system, the suppression of the body constitutes the condition and prerequisite for literate achievement. Such mechanisms are part and parcel of teaching literacy to children, who must learn what bodily parts and postures are connected to literate practice, and what restraints must be visited on movement and the body for the sake of literate practice. ${ }^{9}$ Prose itself is a literate language believed by the textual communities that value it to be most expertly performed when the body that has produced it does not appear in it. ${ }^{10}$ At its most formal and scholarly, prose has traditionally been distinguished from speech, or language in which bodily agency is undeniable, by displaying no trace of dialect, pitch, gender, none of the vocal hesitancies that characterize speech and, above all, no trace of the physical agony of composing it. Well-formed prose should contain no evidence of sleepless nights, binged food, filled ashtrays, or hair ruffled in the service of arranging resistant letters on the page. While the mind is actively engaged in reading and writing, the body is bullied, unnaturally, into quiescence. It rebels and behaves badly.

People who write at length and in private spend hours locked in battle with their bodies. The need to be fed, comfortable, and rested insures that the biological body will distract and 
subvert textual production. Literate wills strike back with ingenious body-destroying behaviors that are widely practiced and rarely acknowledged. In addition to putting pen to paper or finger to key, skin is pulled and scratched, nails, lips and mustaches are bitten, noses, ears and faces are picked, fingernails are peeled, hair is plucked and twisted. "Even when passages seemed to come easily," Annie Dillard writes, "the manuscript revealed the usual signs of strugglebloodstains, teethmarks, gashes, and burns."11 "No sooner was I seated than my head filled with fog,' wrote Jean-Paul Sartre. "I chewed at my nails and frowned."12

In addition to the ordeal visited by literacy on the battling, suffering body, there are strong associations between literacy and a range of taboo bodily behaviors. Not the least of these is taking drugs, since writing provides the occasion and the social excuse for ingesting addictive substances such as nicotine, caffeine, and alcohol, to name the legal ones. Bakhtin provides a vivid example, having been said to have smoked his own work, the prospectus, preparatory sections, and conclusion of a lost project on the Bildungsroman when cigarette papers were in short supply in Russia during World War $11 .{ }^{13}$ For some writers masturbation is a common compulsion, described at length in the private journals of John Cheever. ${ }^{14}$ W.H. Auden may have been on to something in declaring that "most people enjoy the sight of their own handwriting as they enjoy the smell of their own farts." ${ }^{15}$ Literacy wrongly practiced or, more likely, practiced by the wrong people, has been said to precipitate illness and bodily malaise. The Ladies' Guide of Des Moines informed its readers in 1882 that "reading of a character to stimulate the emotions and rouse the passions may produce or increase a tendency to uterine congestion." Further, "the novel-devotee is as much a slave as the opium-eater or the inebriate." ${ }^{16}$ Literate acts aim at dissociating mind from body. To practice literacy is, at the very least, to disguise and repudiate the body. At most, it is to damage or destroy it physically, morally, and emotionally. Leon Poliakov quotes survivor testimony from Auschwitz where knowledge of bodily destruction could be managed only within the frame of an emotional control associated with literacy:

The glow from the crematories could never be escaped, and yet "with the calmness of a citizen reading his newspaper," the deportees told each other in the morning how many convoys had arrived, how many people had been gassed-the day's news. ${ }^{17}$

The meaning of literacy must be continuously inferred and deduced from the set of human relationships that texts express in the norms and practices, lexical and social, which surround them as communicative objects. The fact that the body is as constant an element of literate practice as text itself makes it a stable reference point around which to observe literate practices as cultural phenomena. ${ }^{18}$ If texts are not as distinctly marked off from the performative and evocative acts of bodies as they are assumed or desired to be, if literacy is not exclusively a mental skill, any conceptual shift to the notion of literacy as an embodied practice has important consequences. To give bodily routines and practices associated with textual display and performance their due, it is necessary to extend literacy studies to topics dial have excited little interest or legitimacy in examinations of literacy as a cognitive skill. 
Consider as a test case a contemporary event in American literacy: the Tate-LaBianca murders committed by members of the Charles Manson family in 1969. Among the facts reported to an attentive public were that PIGS had been written in Sharon Tate's blood on a wall at her house. DEATH TO PIGS was written in blood on the walls of the LaBianca house, along with HEALTER SKELTER, a Beatles lyric, misspelled. WAR was also carved into the chest of another victim, Leon LaBianca. In his autobiography, the Manson family patriarch recalled himself as an illiterate pimp, linking the most debased of literate conditions to the despised occupation of trafficking in flesh. ${ }^{19}$ If Manson's self-loathing suggests the boundary conditions of a demonology about the perils of illiteracy, these particulars of the Tate-LaBianca murders are extreme examples of a conventional wisdom that failure to perform according to normative literacy standards is a serious social disqualification from the life of modern communities. But what accounts for our special shock at bloody writing on the wall, a spectacle that makes grisly murders still more horrifying? And of our relief that Healter Skelter is misspelled? Perhaps it is that this bloody alphabet makes too explicit the link from text to flesh, a link that disturbs a moral and social order organized by degrees of bodily separation.

\section{ANTHROPODERMIC BIBLIOPEGY}

An equally dramatic, but far more unexpected, example of flesh joined to text provides the occasion to examine this connection in depth: the historical practice of binding books with the human integument, a practice professional bookmen call anthropodermic bibliopegy, a textually esoteric term of art. ${ }^{20}$ In popular consciousness, the historical manufacture of artifacts from human skin is inscribed as a condensed symbol of the terror of the Nazi regime over enemies and outcasts. A popular source relates that Ilse Koch, wife of the commandant of Buchenwald, ordered prisoners with tattoos to be executed and their skins processed into lampshades, wallets, and book bindings. ${ }^{21}$ Another says the SS used human skin to manufacture saddles, lampshades, riding breeches, and book covers. ${ }^{22}$ We want to know more. Did the Nazis invent this process or learn it elsewhere? So strong is the symbolic efficacy of Nazism in the late twentieth century that its mere mention in connection with books bound in human skin suggests a self-evident etiology, though reliable evidence of Nazis using the skins of corpses to bind books is elusive.

There are earlier sources than this for the practice of binding books in human skin. Moreover, scattered examples of books, for which the claim is made that they were bound in human hide mostly in the late nineteenth century, exist in a number of public and private collections. There is also a large, if fragmentary, antiquarian literature about binding the human integument as an exotic indulgence of book collectors and other high culture denizens. The literature of binding fine books in human hide is a dry subset of a more dramatic popular literature on the uses to which flayed human skin has been put. The most extensive English-language source on anthropodermic bindings of which I am aware is an unpublished monograph written by bibliographic historian Lawrence $S$. Thompson in $1949 .{ }^{23}$ It is concerned chiefly with detailing and authenticating its many examples, no easy task. Because there is nothing perceptibly 
obvious about a book bound in human skin to suggest its composition, in this literature the magical nature of the subject matter makes it especially difficult to distinguish fantasy from fact.

Among texts falsely claimed to be bound in human skin is a volume in the incunabula collection of the Library of Congress. Scrutinium Scriptiuarum is thought to have been written by a priest of the Abbey of Burgos, Pablo de Santa Maria, a converted rabbi, who died in 1435 . The volume is one of 3,000 manuscripts in the Vollbehr collection, including the Saint Blasius-Saint Paul Gutenberg Bible, purchased in 1930 from Otto H.F. Vollbehr, a German industrial chemist and war profiteer, for $\$ 1.5$ million. After Vollbehr spent five or six thousand dollars of this sum to finance issues of a pro-Nazi tract called Memorandum, he was deported, reportedly on the last boat from New York to Germany before the outbreak of war. ${ }^{24}$ Vollbehr claimed that the old wooden boards of the large folio volume, believed to have been printed at Strasbourg in 1469, were covered with human skin in the nineteenth century. In the wake of persistent rumors, the Library of Congress sent the volume for testing to the FBI, which determined that the skin was ox or bull.

Houghton Library at Harvard, Lane Medical Library at Stanford, Van Pelt Library at the University of Pennsylvania, the Boston Athenaeum, and the Newberry Library all hold volumes said to be bound in human skin. ${ }^{25}$ Bookbindings made from the human integument during the late nineteenth or early twentieth century were attached to rare or high culture texts. Their original collectors were often medical practitioners, a number of whom tanned the skin for the bindings themselves. Several of the inhabitants of the skins in their untanned state had been indigent patients of these physician-collectors. Signed, handwritten notations by either the binder or collector appear on tile flyleaves of such volumes to attest to the composition of the bindings. We may think of these texts as model, body-concealing displays of embodied literacy. Human bodies were made quite literally into texts by physicians whose power to textualize them in a variety of ways was a critical element, we shall presently argue, in the emergence of medical practitioners as a rising professional class.

In 1910 in Germany six eighteenth-century anatomical tracts by Bernhard Siegfried Albin us, published between 1736 and 1741 and supplemented with rare color-plate illustrations by Jan Ladmiral, were bound in human skin in a single volume. ${ }^{26}$ The possessor of the flayed skin was probably Dr. Hans Wilhelm Karl Friedenthal, whose name appears with that of the illustrator on a silver repousse plaque modeled and engraved by a prominent Weimar sculptor and set into the cover. The plaque, in the form of an ex libris, displays two stylized profiles, a head and a skull, both with "negroid" features. The end papers are of moleskin and the flyleaf of molegray silk. An inner leaf is inscribed in German, "This book was bound by me in human skin. Berlin. I June 1910. PaulKersten." 27 Kersten, a well-known binder, enjoyed a reputation for skill in human leatherwork. According to his own testimony, he had bound six such books. The Albinus tracts were bound originally in white skin dyed black, possibly to symbolize one of them, On the 
location and cause of the color of Ethiopians and of other peoples. The volume was acquired in 1932 by Stanford, where it is today. ${ }^{28}$

The Houghton Library at Harvard holds another book said to be bound in human skin, Des destinies de l'ame by Arsene Houssaye (1815-1896). A member of fashionable French society during the Empire years of Louis Philippe, Houssaye earned his living as an essayist, critic, and novelist, and as Director of the Comedie Francaise. This volume features an autograph presentation to "mon cher docteur Bouland," who had it bound sometime after its publication in the 1880s in skin "from the back of the unclaimed body of a woman patient in a patient in a French mental hospital who died suddenly of apoplexy." ${ }^{29}$ The skin was not tanned into leather but made into vellum and crafted into a full binding. An inserted note by Dr. Bouland reads:

This book is bound in parchment made from human skin. To display its character no other decoration is placed on it. If examined carefully, the pores of the skin may easily be distinguished. A book on the human soul deserves its own human cover: I had long saved for the purpose this skin from a woman's back. It is curious how the character of the skin varies with the manner of treatment. This volume may be compared, for example, with a little volume that I have in my library, Sever's Pinaeus de Virginitatis, also bound in human skin but tanned in sumac. ${ }^{30}$

The book was given to Harvard in 1934 by John Batterson Stetson, Jr. (1884-1952), son of the Philadelphia inventor and manufacturer of the Stetson hat.

\section{A PECULIAR TENDENCY OF MEN MEDICAL}

At least five anthropodermic bindings survive in Philadelphia; One was the property of Joseph Leidy (1832-1891), a renowned medical scholar and anatomy teacher. Four others belonged to John Stockton Hough (1845-1900), a socially prominent physician. Leidy was a leading American naturalist of his day, hailed as his country's most eminent teacher of human anatomy. Among his achievements was a classic paper on the fossil horse of America, important contributions on the structure of the liver, and the discovery and observation of trichina spiralis in pork. The founder of American vertebrate paleontology, an expert on parasitology, helminthology, zoology, botany, mineralogy, and geology, Leidy received the Lyell medal from the Geological Society of London (1884) and the Cuvier medal from the Institute de France (1881). A member of some 40 professional honorary societies, Leidy authored some 600 scientific notes and articles. At age 30, he took up the chair of Professor of Human Anatomy in the Medical School at the University of Pennsylvania, a post he held for the rest of his life. His Elementary Treatise on Human Anatomy (1861) was the authoritative text on the subject for half a century. His ashes reside in a copper urn at the Wistar Institute of the University. ${ }^{31}$

In 1933, well before the world had occasion to know about Nazi atrocities, Helen Caster Leidy, widow of Leidy's nephew, presented a first edition Human Anatomy, half-bound in human skin, on behalf of herself and her children to the Philadelphia College of Physicians. Her hope was that this "cherished possession" of her husband's might be placed on view for members and 
visitors. ${ }^{32}$ A flyleaf inscription in Leidy's hand states that the skin belonged to a soldier "who died in the great southern rebellion," the likely subject of one of sixty or so autopsies Leidy performed during the war as an examining physician at Satterlee Army General Hospital. ${ }^{33}$

What sort of man was Leidy? What was the framework in which having a text of his own creation bound in human skin made sense? Contemporary accounts portray Leidy as a kind and temperamentally civilized human being. His friends' stories were fond, marveling "at his wondrous learning, or at what he could do with his eyes, his hands, and his microscope." ${ }^{34}$ All but one, a story about the "peculiar tendency of men medical," concerning the acquisition of two adipocere or "petrified" bodies for the Wistar and Horner Museum at the university. ${ }^{35}$ Leidy identified them in museum records as yellow fever victims from 1792, a year in which there was no yellow fever in Philadelphia. The victims' names appear on no census records, and the graveyard from which they were said to have been recovered never existed. ${ }^{36}$

According to the story, the caretaker of the cemetery spoke of violated graves when Leidy asked for the bodies, but hinted he would release them to relatives. Leidy hired a furniture wagon, claimed the bodies as those of his grandfather and grandmother, and rewarded the caretaker generously. The story depicts standard grave-robbing practices of the period by medical practitioners for whom paupers' corpses. provided raw material for classroom demonstrations. ${ }^{37}$

John Stockton Hough hailed from an upper-crust Pennsylvania family descended on his mother's side from a signer of the Declaration of Independence, Richard Stockton. His father's ancestor, Richard Hough, came to America in 1683 with William Penn and rose to high office in the state. In 1868 Hough earned his medical degree from the University of Pennsylvania with a dissertation on sexual reproduction, a subject which sustained his lifelong interest. ${ }^{38} \mathrm{~A}$ collector of rare medical manuscripts, he compiled the first catalogue of medical incunabula. ${ }^{39}$

Drawing his clientele from the elite circles of the Union League and Philadelphia Athletic Club, Hough practiced medicine in Philadelphia in the early 1870s, traveling in Europe and the United States to medical schools, museums and libraries in search of the bibliographic artifacts that fascinated him. In the late 1880s he became a gentleman farmer in Ewing Township near Trenton, New Jersey, ran for political office, and pursued his manuscript collecting with the advice and assistance of the printer and bibliophile, Robert Hoe. His collection included an eighteenth-century treatise by Robert Couper, Speculations on the Mode and Appearances of Impregnation in the Human Female. ${ }^{40}$ Hough had this volume bound in the thigh skin of the patient whose body had provided the occasion for his own first appearance in the medical literature. Two volumes, in fact, were bound in the skin of Mary Lynn, as he identified her, a twenty-eight-year-old Irish widow dead of consumption at Philadelphia Hospital, the Almshouse facility where resident physicians learned their medical skills on paupers' bodies.

According to flyleaf inscriptions, Hough autopsied Mary Lynn and tanned her flesh in 1869 . The same year, his article textualizing her body was published in the American Journal of Medical 
Science. That article, pasted in the Couper volume, described Hough's discovery in Mary Lynn's muscle tissue of the first Philadelphia case of encysted trichina spiralis larvae, the organism Joseph Leidy had spotted in pork. It related that the patient was visited in the hospital by friends who "invariably brought her ham and Bologna sausage, of which she ate ravenously." 41 Pasted in the same volume was a small printed item quoting a French journal, "La Halle aux Cuirs." It claimed that the Library of Marlborough House in Yorkshire contained two hooks bound in the skin of Mary Ratman, a witch executed for murder early in the nineteenth century. These items pasted in the treasured volume by the illustrious Couper, itself bound in the tanned skin of Hough's patient, were the focus for three elements of Hough's textual identity: his desire for personal recognition within a textual tradition of medical expertise descended from the prestigious likes of Couper, his practitioner's knowledge of the esoteric craft of human skin tanning applied to bookbinding, and his upper-class avocation of rare-book collecting. What connections may be fashioned among the tanner's skill, the physician's specialist medical knowledge, and a fondness for rare, old books, to illuminate our grasp of a social code that locates books bound in human hide in the libraries of distinguished physicians and collectors? What, further, do such connections tell us about the relationship of bodies to texts in literate practice? Perhaps there are additional clues in the other hide-bound books of the Hough collection.

The first is Robert Drelincourt's De Conceptionae adversaria, bound in the tattooed wrist skin of a man who died at Philadelphia Hospital in 1869. ${ }^{42}$ Another anthropodermically bound volume was the Catalogue des Sciences Medicales from the Bibliotheque Imperiale, published at the order of the Emperor as two volumes, one in 1861, a second in 1873, describing together some 33,946 items. ${ }^{43}$ Both catalogues were bound in a single large folio with a chirographic note stating that the binding was skin from a human back, tanned in 1887 and bound the next year.

The last hide-bound volume in the Hough collection, also from the skin of Mary Lynn, was the seventeenth-century text, Recueil des Secrets de Louyse Bourgeois, the first French book on midwifery written by a woman. ${ }^{44}$ Louyse Bourgeois was midwife to Marie d'Medici, queen of Henry IV of France. In 1627 she was mistakenly accused by royal physicians of leaving afterbirth in the womb of the duchess and causing her death from childbed fever. Bourgeois was literate and had been trained by her husband, a student of the famed obstetrician and surgeon Ambroise Pare. She defended hands-on practitioners against her textually trained accusers. "By your report," she wrote, "you expose your utter ignorance of what constitutes a woman's afterbirth .... So does your master, Galen, who although a bachelor and with very little midwifery practice, presumed to teach midwives by a book, which shows that he knew absolutely nothing of the gravid womb, and less of the afterbirth." 45 She concluded, "Medicine is a science embracing many branches, such as pharmacy, and surgery with its numberless subdivisions, all of which depend more on Practice than on Theory." 46 Hough was surely interested in Bourgeois' contributions to the study of pregnancy. Notes in his own hand embellish the margins of a copy of a lecture on her life by William Goodell to the Philadelphia County Medical Society. Her story dramatizes the conflict between a body-based craft of 
healing and a textualized, theoretical medicine divorced from clinical practice, a conflict that remained unresolved until the nineteenth century.

Like Leidy, Hough the collector was widely read and of broad interests. Although not of Leidy's scholarly rank, he was the author of 30 papers on hygiene, biology, speculative physiology, social science, vital statistics, population and political economy. He was said to be an authority on human monsters. He invented a vaginal-rectal speculum and a method of fireproof building. He had progressive leanings. He wrote articles arguing that women unjustly paid higher life insurance premiums than men because of a misconception about their greater frailty, that Jews were a better life insurance risk than other ethnic groups and that contrary to conventional wisdom, mortality rates were better for rural than urban inhabitants. An article he authored for a poultry journal on techniques for producing desired-sex offspring in chickens was edited for language the editor felt would offend "fastidious" readers of his family journal. A devoted "wheelman," Hough supported and helped build the first macadamized road in Mercer County.

All this is detailed in a scrapbook of articles and correspondence assembled by Hough to display his textual persona. ${ }^{47}$ Prominently placed is a clipping from the Trenton Times describing the diamond ring on his finger, a gift of James Gordon Bennett, the fire and burglar-proof vault, in which Hough kept his rarest books, a vellum page of the Gutenberg Bible hanging in his library and valued at $\$ 50$, and his study, "a large, cheerful room in terra cotta, with an open fire place, luxurious chairs, handsome, crowded book cases, and pictures and relics, the result of Dr. Hough's fourteen trips across the Atlantic." The reporter described how the subject of his story

took book after book in hand, calling some "beauty," "marvelous gem," "nugget" and "as exquisite as valuable," spanning five centuries of life with a most entertaining bridge of knowledge, which partook of history, art, science and literature, colored and animated in a high degree. ${ }^{48}$

His prized books included a 1403 edition of Johannes de Ketham's Fasciculus Medicinae, its fullpage illustrations said to be among the earliest color prints of individual organs. One of them, "The Anatomy Lesson," depicts a physician seated in an elevated chair supervising the surgical dissection of a body, emblematically portraying the privilege of the physician as master of the text to oversee the work of practitioners. ${ }^{49}$

\section{PHYSICK AND SURGERY: A TEXTUAL DIVIDE}

It is in the context of the professionalization of medicine, especially surgery, that the significance of the avocation of some medical practitioners for collecting books bound in human skin in the late nineteenth and early twentieth centuries begins to suggest itself. We start with a brief account of the history of medical knowledge as a struggle between the body and the text. Centuries of conflict between knowledgeable practitioners of the body and masters of textual and theoretical expertise had given rise to a divide in European medicine between the intellectual art of physick and the practical art of surgery. In this struggle claimants to textual mastery seized the permanent advantage. 
The Christian doctrine of the physical resurrection of the corpse was one source of tension between knowledge derived from analyzing texts, a kind of dissection, and from dissecting bodies, a kind of analysis. Medical practice of all kinds was suspect among the highest ranks of the clergy and accompanied by specific doctrinal disapproval of anatomical dissection.

Traditional beliefs about the essential connection between the body and the soul for a specified period following death, along with traditional customs that placed the corpse at the center of funerary rites, stoked popular fears of medical grave-robbing, and nourished popular resistance to dissection well into the nineteenth century.

Medieval medicine was a textual discipline. Its great authority was Galen, for whom surgery was only one treatment among many, and whose anatomical evidence came from apes and pigs, traditionally despised animals, instead of human bodies. In 1163 the Council of Tours forbade clerical physicians to practice any treatment that shed blood. Along with dentistry and bloodletting, surgery became a practice of tainted craftsmen and itinerant tradesmen such as barbers, bathkeepers and sow-gelders, all of whom were outside Church organization. ${ }^{50}$

During the Renaissance, the gradual weakening of ecclesiastical authority permitted artists to study the human body by dissecting cadavers. Confidence in clerical physicians who could little ameliorate the effects of war and disease declined as battlefield surgeons made significant gain in surgical knowledge. While some Continental surgeons attended universities and taught as members of faculties, few enjoyed equal status or pay with physicians. In England, most surgeons did not have university training, and most practitioners were barber-surgeons practicing under the authority of local guild law. The sixteenth century saw a codification of the separation between literate physicians and artisan surgeons. Physicians distinguished themselves from surgeons, and surgeons distinguished themselves from barbers. The physician claimed the right to practice surgery as a part of physick, which he interpreted as a privilege to direct the surgeon. The physician often received his degree without ever examining a patient. His training was almost entirely academic and classical.

In England, the charter granted to the United Company of Barber-Surgeons in 1540 restricted barbers' surgical operations and entitled the Company to the bodies of four executed criminals each year "for the purpose of dissection and study of anatomy." By 1752 a parliamentary act gave judges the latitude to substitute dissection of the executed corpse for gibbeting in chains in murder sentences. Ruth Richardson points out that granting physicians the right to dissect criminal corpses made them executors of the law, and reinforced the perception that socially ambitious surgeons and physicians suffered the poor and outcast as economically necessary to their work, but otherwise a nuisance class. At least some physicians recognized the contradiction. William Horner, a colleague of Leidy's, urged that "every legislature should abolish that which consigns the bodies of malefactors to the surgeons as the last act of human degradation." 51 Medically staffed charitable institutions conferred a public motive of humanity on doctors whose status was advanced on the backs of those helplessly within. Inhumanity by doctors was rationalized as a necessity of clinical detachment. Any gap in this interpretation 
was justified by claims that those who were useless to society in life might redeem themselves in death.

Increasingly, the unavailability of clinical experience at Oxford and Cambridge, which furnished the degrees necessary for admission to the Royal College of Physicians, was seen as an educational liability. The monopoly of the Company of Barber-Surgeons on the work of dissecting bodies made systematic anatomical teaching legally impossible. London and Edinburgh attempted to fill this gap by combining the resources of the hospitals, that is, the indigent sick, with a more aggressive medical curriculum. ${ }^{52}$ Other solutions emerged in private anatomy schools like the one opened in 1748 by William Hunter (1718-1763), the future Physician Extraordinary to Queen Charlotte, a precursor to his famous anatomy school with its own museum. Hunter had no legal source of cadavers, but his connections with resurrectionists enabled him to offer every student access to an individual corpse in the. French manner of teaching. His student and younger brother John Hunter (1728-1794), a key figure in the development of comparative anatomy and experimental surgery in Britain (and the reputed possessor of a treatise on pathological dermatology bound in a healthy cured human skin) amassed a still more famous anatomical museum that became the basis of the collection at the Royal College of Surgeons in London. All major medical centers had such collections by the nineteenth century.

The symbolic battleground on which the medical body and text met is depicted in the story of John Hunter's first meeting with Philip Syng Physick, the first professor of surgery of the medical school of the College of Philadelphia. Physick's father brought him to London to be apprenticed to Hunter, whose rough, unschooled exterior and surgical brilliance were legendary:

When asked by the father what books his son would be expected to read, Hunter with characteristic force and earnestness said: "Sir, follow me; I will show you the books your son has to study," and leading the way to the dissecting-room, he pointed to several bodies, adding, 'These are the books which your son will learn under my direction; the others are fit for very little. "53

A more democratic tradition of apprenticeship and the absence of an aristocratic class created a less hierarchical medical profession in the United States. ${ }^{54}$ The first medical school in the colonies opened in 1765 at the College of Philadelphia, later the University of Pennsylvania. Its success was partly due to its provision of clinical experience through ready access to hospital facilities. This valuation of clinical training strengthened the link between the University of Pennsylvania medical school and Blockley Hospital, the readiest source of cadavers in the city. By mid-nineteenth century, the well established industry by which the Almshouse produced bodies for clinical instruction and surgical demonstrations had given rise to a popular unease about suspected abuses sufficient to set off occasional riots. 
Having thus acquired skill in the tacitly authorized, but still disturbing, violation of the sanctity of the corpse, anatomists and surgeons joined physicians in a literate quest for greater social and professional status during the nineteenth century. The sensitivity of the social and moral borders at issue is suggested in a recollection by a Professor Emeritus of Obstetrics at the University of Pennsylvania, concerning his entrance to medical school in 1880 in a depressed state because of his family's disapproval of his chosen occupation. The operator in his first course at the surgical clinic "belonged to the old school of surgeons who gloried in making an operation look as gruesome as possible, among other things holding the knife in their teeth when it was not in use." 55 Surgeons, medical craftsmen who worked with their hands, began to make their reputations by fabricating textual knowledge as well as by apprenticeship and demonstration. They gained prestige and power by textualizing their patients' bodies, and displayed themselves accordingly.

Scholars have neglected the dose connection between textuality and the history of medical professionalization, though its special markers -- degrees, licenses, and learned and professional societies organized around textual production and communication -- all testify to the prestige of textual modes. Arnold Thackray has written that nineteenth-century scientific discourse was a mode of cultural self-expression for legitimating socially marginal men, and that the rhetoric of science far exceeded its therapeutic efficacy for most of the century. ${ }^{56}$ Science was what its various champions, seeking to justify professional prerogatives and enhance socioeconomic stature, said it was. Among physician users of the new rhetoric, the term scientific was an expert designation signifying textual mastery and production.

Increasing textual demands were placed on nineteenth-century practitioners. In 1848 the fledgling American Medical Society issued the first report of its Committee on Medical literature. It named the major medical journals for its members and described what good medical articles ought to be like. ${ }^{57}$ The report lamented that Operative Surgery, its practical "handicraft" character manifest in its traditional name of chirurgery, had the largest number of published contributions to show for the year at the expense of "higher" fields like anatomy and physiology. Being presumably more theoretical, these fields would be more amenable to textual elaboration.

The following year the committee spelled out its goals. Employing a vivid somatic metaphor for the textual transition deemed essential to the student and the profession, the Committee argued:

[T]he intellectual powers must be disciplined and trained to authorship whilst the mind is undergoing collegiate culture. The pen must be familiar to the hand, ere the fingers contract any of the rigid immobility of age; for if not early familiar to their endeared embrace, it will yield a very reluctant tribute to science. ${ }^{58}$

Preceptors must demand written communications from students. Medical societies must offer prizes for good essays. "The Faculties of our medical schools should, themselves, present the 
examples and the models of writing" by disseminating "substantial proofs" -- that is, texts -- to demonstrate their commitment to the progress of medical knowledge.

If oral demonstration had once occupied pride of place in the display of medical expertise, the new standard was textual. "Skillful diagnoses, judicious medication, or bold and successful operation, if not properly recorded," wrote John Shaw Billings in 1876, "benefit the individual only, not being available for those compari-sons and higher generalizations which alone can make medicine a science. " 59 A prominent surgeon, librarian, and statistician, Billings (18381913) built a national medical library in the Surgeon-General's Office, collected medical statistics during the Civil War, and founded the Index Medicus, the major catalogue of medical research in the United States. He counted a single medical book by an American author at the beginning of the Revolutionary War, three reprints, and about twenty pamphlets. By 1876 , there were 1,176 first and later editions of medical texts, 336 volumes of medical society transactions, and 1,274 first and later American editions of foreign reprints. ${ }^{60}$ Between 1797 and 1850, 117 medical journals were begun in the United States; 275 were published by the end of the century. In 1800 the country boasted only four medical colleges. By 1877 there were 73. 61

\section{ANTHROPODERMIC DISPLAY}

Each of the expensively bound anthropodermic volumes in Philadelphia was an upper-class creation of a prestige artifact fabricated literally out of the grotesque bodies of the poor and dispossessed. Books bound in human skin were devices to enhance the social position of their owners, exhibiting them as connoisseurs of finely crafted objects accumulated by a discriminating class, and as priestly magicians transforming the bodies and fates of others. This display of invisible or more precisely, disguised, bodies--once pitilessly exposed, unlovely and decaying cadavers, now dressed up in fine bindings--was impeccably tasteful. While the medical violation of the pauper's body marked it as Other by depriving it of the dignity of its own physical boundaries, its visible identity as someone's body, and its customary cultural adornment, the literate appropriation of the denuded Other claimed it as a token of the symbolic bourgeois body--closed, smooth, and unorificed. The low body reconstituted as high binding was mute covering and concealment for the disembodied bourgeois text.

Bakhtin's notion of the classical and grotesque body as key terms has much to offer the analysis of anthropodermic bindings as a discourse of social and cultural borders. ${ }^{62}$ The book bound by physicians in human skin contrasts the socially elevated and inviolable body of the medical practitioner with the grotesque and permeable body of the patient-pauper, its orifices multiplied, their horror exaggerated by gaping wounds medically inflicted. If assisting patients is the physician's vocation, the nineteenth century is a narrative of patients helping doctors or, put a different way, of helpless but willy-nilly helpful paupers powerless to resist a medical establishment in need of them as raw material. Warehoused in hospitals and poorhouses, at the mercy of a science filtered through professional ambition, it is little wonder the poor 
developed a persistent folklore active into recent memory, in which those of their number who went to the hospital never came back.

The human hide-bound book was situated in the scholar's library and the museum, entitled private places of bourgeois prerogative, marked off for the contemplation of exotic souvenirs of the Other and layering cultivated gentility over what might otherwise appear as barbarous appropriation. As an expression of bourgeois self-possession at a point of moral ambivalence and sensitivity, the book bound in human skin was a talisman to ward off the ghosts of the slain, a device for re-framing as cultivated refinement some lingering guilt for the transgression of powerful bodily taboos, a Freudian manifestation "of remorse, of admiration for the enemy, and of a bad conscience for having killed him." ${ }^{63}$ Borrowing the argument of Norbert Elias that the disciplined body is fundamental to bourgeois sensibility, it follows that disgusting bodies cannot be bourgeois. Since all bodies are potentially disgusting, pains must be taken to segregate bourgeois bodies from others. "What is it which makes us differ from the most degraded inmates of this house?" asked David Hayes Agnew, a celebrated surgeon who was a colleague of Leidy's and a chronicler of the Philadelphia Almshouse, beseeching his colleagues for more charitable treatment of its inmates. "Nothing; really nothing, by the grace of God."64

Partly because of the risks implied by this confusion, the body of the pauper could be violated, invaded and reformed. The Other as raw resource, unpleasant, malodorous, deprived of any saving cultural grace, but above all vulnerable and abject, was to be sacrificed, purified, and physically, socially and cognitively reconstructed as disembodied culture, as text. As pauperpatient, the Other was violently corporealized; as corpse, decorporealized, or stripped of identifying bodily singularity, and transformed into an elegant bibliographic artifact bearing no resemblance to the grotesque body from which it had been made. Suitably admissible to the library of the bourgeois physician, the anthropodermically bound book was a trophy to professional skill and textual connoisseurship used aggressively against one class for the sake of defining another. It was, at the same time, an expiation of the sacrifice of the former class through totems of appeasement, affection, and pride lovingly crafted by the latter. What made it morally defensible to use the poor in this fashion, a rationale prone to slippage and in constant need of refurbishing, as periodic scandals suggest, was the social construction of the indigent and outcast as surplus people good for little except their own degraded bodily pleasures, but useful at least for medical science or, in the case of the bound book, for indulging the esoteric intellectual interests of medical practitioners. ${ }^{65}$

Binding fine books in the skins of the poor carved out of their distress a social domain of order, civility, and decorum. Like medical body-snatching, it made of the poor a resource for the production of physicians. The human hide-bound book constituted part of the cultural identity of the physician to whom it belonged by defining its owner's distance from the powerless, while effacing the conditions of its production so as not to risk bourgeois sensibilities. That these sensibilities were at risk was evident from the diary of William E. Horner's trip to Europe in 1821 to inspect the principal European anatomical schools and collections, and to meet with such 
medical luminaries as Sir Astley Cooper, one of the most famous resurrectionists of his day. ${ }^{66}$ Horner was deeply shocked by a visit to the Anatomical Theater of Amsterdam:

A singular and disgusting taste is displayed here in having the skeletons of men dressed up with their old hats, wigs, cassocks, pantaloons, etc.

The women with their caps, petticoats, jackets, etc., they are thiefs and whores who were hung.

The skeleton of one man in particular dressed up, mounted on a mule with the horn which sounded before him as he went to the execution.

This barbarous taste gave a degree of gloominess to the business which I scarcely ever felt on visiting a collection before and interfered much with the pleasure I should otherwise have felt in the reflection that I am now under the roof hallowed by the labors of [Frederic] Ruys[c]h. ${ }^{67}$

In Horner's view, the proprietors of the famous anatomical amphitheater had not sufficiently erased the corporealized existence of these medical subjects in transforming them into products of the labor of distinguished physicians. This failure to reconstruct them to the specifications of the non-theatrical, non-moralizing, scientific collection Horner may have had in mind can be traced to the history of the Continental amphitheater as the setting of a permanent morality play for generations of popular audiences at the public anatomies conducted there. Popular texts and pictures made much of the cycles of life and death and good and evil that were prominent themes in these traditional fetes, the subjects of which were mostly felons until the late seventeenth century. ${ }^{68}$ Amsterdam's rival, Leiden, had six galleries with seating for several hundred observers. Seventeenth-century prints show animated skeletons displayed there with "messages of moralizing intent." ${ }^{19}$ Bologna, where public anatomy originated at the beginning of the fourteenth century, had constructed by midsixteenth century a "sumptuous and lordly" theater, the site for 150 years of theatrically splendid public anatomies attended by scholars, representatives of Church and city, and spectators who wore masks when anatomies took place during Carnival, as they regularly did. ${ }^{70}$

In its display of anthropodermic curiosities, the scholar's library rejected this overtly moralizing logic. In anthropodermic bookbindings the bodies of the poor, stripped of cultural signifiers, were decorporealized into pure text that evaded questions of morality by concealing both the circumstances and materials of textual production. ${ }^{71} \mathrm{If}$, for us, the manufacture of artifacts from human skin recalls Nazism, the most relevant. reference for Joseph Leidy and John Hough was the public anatomy. By comparison, their own appropriation of human skin was refined, genteel, and even a fond tribute to its original inhabitants. The visible connection of these bindings to the bodies they had been was almost completely concealed. Anthropodermic bindings are easily mistaken for pigskin, morocco, deerskin and even sheepskin. ${ }^{72}$ Notice of their special character had invariably to be taken in inscription. The variability of their 
appearance suggests the plasticity of meanings and statuses assigned them. Such interpretive flexibility in the physical object was socially useful.

The binding of books in human skin by physicians has a powerfully suggestive relationship to the emerging professional medical practice of transforming patients into texts. The anthropodermically bound book combined the surgeon-anatomist's craft as a cutter of flesh with the literate prestige of the medical scholar. If the book bound in human skin was a finely worked objet, it also concealed its true relationship to the patient-body that formed the raw material of the doctor's profession and effected his community standing. ${ }^{73}$ The choice of technical or esoteric medical texts for binding reflects the social exclusivity of a profession that guarded its initiatory secrets in complex rituals of bodily and textual practice. Unlike the operating theater in the charitable institution that provided a stage to display the surgeon's skill, or the dramatic and moralistic rituals of the public anatomy, the finely bound book concealed its character in the high-culture place of the library, the study, and the specialist scientific museum with admirable discretion.

But what have Joseph Leidy, John Hough, and other collector-physicians to do with persistent tales of Nazi bookbindings? Perhaps what is remembered in the attachment of bookbinding stories to grim and disturbing tales about Nazi doctors as extractors of teeth and flayers of skin, doctors who are simultaneously Other and familiar, are the frightening and seemingly irresistible purposes of those with unlimited control, administered in the name of a superiorizing science, over bodies charged to their care. Perhaps these stories recall and revivify earlier memories of victimized human flesh.

A letter to the editor of the St. Louis Post-Dispatch suggests that stories of physicians and human hide artifacts were available to popular consciousness in the late nineteenth century, and not only esoteric, if reasonably frequent, curiosities in the columns of bibliographic journals. This letter reported the testimony of "solid citizens" that tanning human skin was a not unusual, if little known, business of hide and leather tanners. ${ }^{74}$ "Chiefly surgeons and physicians" were said to be consumers of "pocket-books, spectacle cases" and other items. "Many physicians use bags made of human skin to hold their more delicate instruments, and say it is the best material from which such an article can be made." A prominent surgeon's wife was said to carry a purse made from the skin of one of her husband's patients. It was claimed that two New York coroners and "most of the young surgeons in our hospitals" had instrument bags of human skin. This account admits to the "ghastly" character of the practice with a wellmannered shudder, but there is a tone of identification with the practitioners, perhaps even envy. It is a strange practice, almost not to be discussed in public, but there is none of the horror of violated Christian doctrine, and doctors were said to affect it "not altogether as a fad, but a matter of business." It is a tolerant, interested, even amused secret in a secular middleclass newspaper addressing a world in which physicians were respected by those who could afford them. 
Gruesome and elaborate popular traditions of stories about the preparation and uses of human hide are scattered throughout historical sources in sensational combinations of truth and falsehood. Tales of Nazis binding books with the human integument constitute one such tradition. ${ }^{75}$ If popular culture has inserted human hide bookbinding into the catalogue of Nazi atrocities, removing it from the memory of its former association with respectable doctors to attach it to the practice of doctors gone mad, sundering in this process a critical historical link that makes it available for inspection, there remains only to speculate on the relevance of all this for the antics of Charles Manson. Manson appears to us not as a disreputable inversion of reputable doctors, but as a monstrous challenge to notions of legitimate authority. Carved on bodies brutally murdered for reasons difficult to grasp, the textual practices of Manson's followers were direct, violative, and crude. Nor did they possess as a group the resources of social station to transform their barbaric practices into justifiable and necessary acts. By textualizing the bodies of victims with the ink of their own blood, by appropriating the bodies of victims for any textual use at all, Manson and his followers flirted dangerously with bodyappropriating and power-conferring literacy in a way that contributes to popular fascination with and revulsion toward their crimes. That insiders in the contemporary uses of literacy, which means all socially functional literates, know Healter Skelter was misspelled, helps shatter the spell of that brutally corporealized text, but can hardly dispel the fear of its power.

\section{Notes}

The advice and contributions of many bodies are concealed in this text. The author, an Associate Professor of Communication at the Annenberg School for Communication, University of Pennsylvania, gratefully reveals them to belong to Pete Daniel, Janice Fisher, Robert Friedel, Larry Gross, Tom Horrocks, Pam Inglesby, Kathleen Hall Jamieson, Ramona Lyons, Dennis Marnon, Terry King, Jan Machelski, David Nord, Robert Peck, David Perlmutter, Charles Rosenberg, Christine Ruggere, Pamela Sankar, Marsha Siefert, Nikhil Sinha, Christopher Smith, Carolyn Spawn, Jim Sprague, Joe Turow, Betty Vadeboncoeur, Peter Van Wingen, and Gretchen Worden. Very special thanks to David Ingle and Amy Sarch. Partial versions of this paper were p presented at Simon Fraser University, the University of Maryland at College Park, and at the 42nd annual convention of the ICA.

${ }^{1}$ Matthew R. Bradley, "Momma' s Boy: A Conversation with Robert Bloch," FILMFAX 40 (1993): 81.

2 The single example of which I am aware is Robert Ochsner, Physical Eloquence and the Biology of Writing (State University of New York Press, 1990), which addresses techniques for teaching writing to college students. 
${ }^{3}$ See Norbert Elias, The Civilizing Process, tr. Edmund Jephcott (1978; New York: Pantheon, 1982); Michel Foucault, Discipline and Punish: The Birth of the Prison, tr. Alan M. Sheridan Smith (New York: Pantheon, 1977); James Clifford and George E. Marcus, eds., Writing Culture: The Poetics and Politics of Ethnography (Berkeley: University of California Press, 1986); Mary Douglas, Natural Symbols (New York: Pantheon, 1982) and Purity and Danger (New York: Praeger, 1966); Francis Barker, The Tremulous Private Body: Essays on Subjection (London: Methuen, 1984); Bryan S. Turner, The Body and Society (London: Basil Blackwell, 1984). For a wide-ranging review of the body in anthropology, sociology, and cultural and literary studies, see Mike Featherstone, Mike Hepworth, and Bryan S. Turner, eds., The Body: Social Process and Cultural Theory (London: Sage, 1991).

${ }^{4}$ Realism, Writing, Disfiguration: On Thomas Eakins and Stephen Crane (Chicago: University of Chicago, 1987).

${ }^{5}$ Francis Barker, The Tremulous Private Body: Essays on Subjection (London: Methuen, 1984).

${ }^{6}$ Fieldwork in Common Places," in Clifford and Marcus 33.

7 See, for example, Carolyn Marvin. "Constructed and Reconstructed Discourse: Inscription and Talk in the History of Literacy," Communications Research 11 (1984): 563-94.

${ }^{8}$ See Marianna Torgovnick, Gone Primitive: Savage Intellects, Modern Lives (Chicago: University of Chicago, 1990). Torgovnick connects the Western notion of the "primitive" to the condition of physicality, but does not recognize it as opposed not only to the modern, but to text as the distinguishing sign of the modern, though many of the tensions she tracks between a banished physicality and a notion of text-based authority suggest this interpretation. Her account of Bronislaw Malinoswki's diaries is especially revealing on this point.

${ }^{9}$ For an imaginative discussion, see Michele Strano, "Growing Up By the Book: Literacy, Power and the Parent-Child Relationship," Unpublished M.A. Thesis, University of Pennsylvania. 1993. See: also Ronald Scollon and Suzanne B.K. Scollon, "The Literate Two-Year-Old: The Fictionalization of Self," in Narrative Literacy and Face in Interethnic (Norwood, New Jersey: Ablex, 1981), for an account of early socialization into literacy through imitative performance.

${ }^{10}$ Confessional and autobiographical writing acknowledge an embodied authorial voice, and contrived embodied voices are common in fiction. As a general rule, the more formal the prose, the more distanced its language from explicit embodiment. Experimental writing that challenges this rule predictably positions itself as subversive.

${ }^{11}$ Annie Dillard, The Writing Life (New York: Harper \& Row, 1989) 29.

${ }^{12}$ Quoted in Alice G. Brand, The Psychology of Writing (Westport, Conn.: Greenwood Press, 1989) 13. 
${ }^{13}$ Katerina Clark and Michael Holquist, Mikhail Bakhtin (Cambridge: Belknap Press, Harvard, 1984) 321.

${ }^{14}$ Robert Gottlieb, ed., The Journals of John Cheever (New York: Knopf, 1991). See Ted Solotaroff, "The Cheever Chronicle," The Nation, 18 Nov. 1991,616.

${ }^{15}$ Quoted in Michael Heim, Electric Language: A Philosophical Study of Word Processing (New York: Vintage, 1968) 17.

${ }^{16}$ Ladies' Guide (Des Moines: W. D. Conduit Co., 1882) N. P.

17 Leon Poliakov, Harvest of Hate, rev. ed. (New York: Holocaust library, 1979) 219.

18 James Clifford has argued for conceptualizing culture as something-besides-text, as positioned utterance.

This notion can be taken to include embodied expression, as examined here, and is central to any notion of text as cultural form and practice. See James Clifford, "Introduction," in Clifford and Marcus, eds., 12.

${ }^{19}$ Charles Manson, Manson in His Own Words / As Told to Noel Emmons (New York: Grove Press, 1986) 222.

20 The term, by virtue of its derivation from the body-detached (that is, dead) languages of the classics, and not the body-based living vernacular, helps distance and conceal its gut-wrenching significance.

${ }^{21}$ Tom Segev, Soldiers of Evil, tr. Haim Watzman (New York: McGraw-Hill, 1957) 140

${ }^{22}$ Robert L. Berger, "Nazi Science-The Dachau Hypothermia Experiments," New England Journal of Medicine 322 (1990): 1435-40.

23 "Religatum de Pelle Humana. Occasional Contributions No. 6. (Lezjogton, Ky.:

University of Kentucky Libraries [unpublished manuscript, 33 pp.] Historical Collections, New York Academy of Medicine library.

24 Peter van Wingen, "The Incunabula Collection at the library of Congress," Rare Books and Manuscript Librarianship 4 (1989): 91-94.

${ }^{25}$ Anthropodermically bound books held in Lane Medical Library, Houghton library, and Van Pelt are discussed in this article. The volume held at Boston Atheneaum is The Life of James Allen, alias George Walton, alias Jonas Pierce, alias James H. York, alias Burley Grove, The Highwayman subtitled, "Being his Death Bed Confession to the Warden of the Massachusetts State Prison." No accession record exists for this volume, said to have been published at the death of its author, a condemned highwayman, in 1837. See "Bound in his own skin," Boston Globe, 9 Mar. 1890; Letter, John A. Fenno to John W. Farlow, 3 Dec. 1921; "Are There Others?" Athenaeum Items, No. 30, Feb., 1944, 2. All items from Boston Athenaeum Archives. A doubtful but, to date, untested book resides in the Newberry Library in the John Mansir Wing collection on the history of printing. It contains a manuscript written in Urdu. A handwritten letter tipped into the back of the 
volume describes its contents in English. The first leaf is inscribed: "Found in the palace of the king of Delhi, September 21st, 1857. Seven days after the assault. [Signed] James Wise, M.D." The reference is to the Sepoy Mutiny against the British. A second inscription in an unknown hand reads, "Bound in Human skin." This volume, too, has no accession record. According to the curator of the Wing collection, the lingering Victorian scruples of the librarians may have been responsible for these omissions.

${ }^{26}$ Charles D. O'Malley, "Notes and Queries: Bound in Full Human Skin," Journal of the History of Medicine and Allied Science 8 (1953): 447-449.

27 Betty Vadeboncoeur, Librarian, Lane Medical Library, Stanford University Medical Center, personal communication to the author, March 5, 1990.

28 The book was bought from Maggs Bros. of London, rare book dealers, whose 1932 Catalogue of Strange Books and Curious Talks singles out the Ladmiral book in its introduction: "For the most remarkable, if somewhat gruesome binding, see item 305, a famous anatomical work bound in human skin."

${ }^{29}$ A typed memorandum by the donor, J.B. Stetson, explaining the book's history, is mentioned in catalogue records, but has been lost. Dennis Marnon, Acquisitions Bibliographer, Widener Library, Harvard University, personal communication to the author, Sept. 5, 1990.

${ }^{30}$ Author's translation. I am grateful to Dennis Marnon for a transcription of the original French.

${ }^{31}$ Absent his brain. This resides at the College of Physicians, a bequest of the Anthropometric Society, to which he willed it.

32 Letter, Helen Caster Leidy to Francis Packard, 2 Jan. 1933. Historical Collections of the Library, College of Physicians, Philadelphia, Pennsylvania.

33 Leidy's work at Satterlee was reported in official communications to the SurgeonGeneral. See Joseph K. Barnes, The Medical and Surgical History of the War of the Rebellion (1861-1865) (Washington, D.C.: Government Printing Office, 1875). 2 vols. In 6 pts.

${ }^{34}$ William Hunt, In Memoriam, Dr. Joseph Leidy. Personal History (Philadelphia: Academy of Natural Sciences, 1891) 9.

35 William Hunt, An Address Upon the Late Joseph Leidy, M.D., LL.D., His University Career (Philadelphia: Alumni Society of the Medical Department of the University of Pennsylvania, 1892) 27-29.

${ }^{36}$ See Joseph McFarland, "Dr. Joseph Leidy's Petrified Lady: Rummaging in the Mutter Museum, of the College of Physicians of Philadelphia," Annals of Medical History, 3rd 
Ser. 4(1942): 268-275. Mutter Museum Director Gretchen Worden has corrected and annotated McFarland's work in light of more recent information.

37 The standard resurrectionist history is Ruth Richardson, Death, Dissection and the Destitute (New York: Routledge \& Kegan Paul, 1987).

${ }^{38}$ The dissertation was The Non-Congeniality of the Elements of Reproduction in the Human Species.

${ }^{39}$ See Fred B. Rogers and Thomas A. Horrocks, "Dr. John Stockton Hough: Medical Bibliophile and Bibliographer," Transactions and Studies of the College of Physicians of Philadelphia II (1989) 355-361.

40 (Edinburgh, 1789), Historical Collections of the Library, College of Physicians and Surgeons, Philadelphia.

${ }^{41}$ John Stockton Hough, "American Intelligence: Two Cases of Trichiniasis Observed at the Philadelphia Hospital, Blockley," American journal of Medical Science 57 (1869): 565.

42 (Lugduni Batavorum, 1686). Historical Collections of the Library, College of Physicians and Surgeons, Philadelphia.

${ }^{43}$ Bibliotheque Imperiale, Department des Imprimes, Catalogue des Sciences Medicales, vols. 1 and 2, comp. Jules Antoine Taschereau (Paris: Librairie de Firmin Didot Freres Filsetche, 1861, 1873). Rare Book Collection, Van Pelt Library, University of Pennsylvania.

${ }^{44}$ (1650). Historical Collections of the Library, College of Physicians and Surgeons, Philadelphia.

${ }^{45}$ William Goodell, A Sketch of the Life and Writings of Louyse Bourgeois, Midwife to Marie de' Medici, the Queen of Henry IV, of France. The Annual Address of the Retiring President Before the Philadelphia: County Medical, Society. (Philadelphia: Philadelphia County Medical Society, 1876) 50. Historical Collections of the Library, College of Physicians and Surgeons, Philadelphia.

${ }^{46}$ Goedell 50.

47 John Stockton Hough, Opera Minora (scrapbook), Historical Collections of the Library, College of Physicians. The flyleaf inscription reads, "The contents of this book were collected and mounted by the author from 1876 to $1886 . "$

48 "With Rare Books. Dr. John Stockton Hough's Library at Ewing," Trenton Times, 22 Feb. 1894. 
${ }^{49}$ For a discussion of this illustration, see Diane Karp, Ars Medica. Art, Medicine, and the Human Condition. Prints, Drawings, and Photographs from the Collection of the Philadelphia Museum of Art (Philadelphia: Philadelphia Museum of Art, 1985) 154.

50 Robert S. Gottfried, Doctors and Medicine in Medieval England (Princeton: Princeton University Press, 1986) 55.

${ }^{51}$ Diary of Dr. William Edmonds Homer of Philadelphia on a Journey to Europe in 1821. Alfred Rives Shand, Jr., transcriber. Vol. 1, No. 5, 10 May 1821.

52 In 1821 Charing Cross Hospital was established as the first teaching hospital in London.

53 S.D. Gross, John Hunter and His Pupils (Philadelphia: Presley Blakiston, 1881) 84.

${ }^{54}$ See Rosemary Stevens, American Medicine and the Public Interest (New Haven: Yale University Press, 1971) 11-20, and Charles E. Rosenberg, The Care of Strangers. The Rise of America's Hospital System (New York: Basic Books, 1987) 60-61, 169-171.

55 Barton Cooke Hirst, M.D., "Some Reminiscences of the Philadelphia Hospital as a Prospective Interne, and as a Member of the Staff for 20 Years," 'Old Blockley,' 128.

56 Quoted in Samuel E. D. Shortt, "Physicians, Science, and Status: Issues in the Professionalization of Anglo-American Medicine in the Nineteenth Century," Medical History 27 (1987): 51-68. Anglo-American physicians were cautious and skeptical about adopting antisepsis and anesthesia, the two major medical innovations of the nineteenth century.

${ }^{57}$ Report of the Committee on Medical Literature, Transactions of the American Medical Association 1 (1848): 254.

${ }^{58}$ Report of the Committee on Medical Literature, Transactions of the American Medical Association 2 (1849): 414.

59 John S. Billings, "Literature and Institutions," in E.H. Clarke, Henry J. Bigelow, Samuel D. Gross, T. Gaillard Thompson, and J. S. Billings, A Century of American Medicine: 17761876 (Philadelphia: Henry C. Lea, 1987) 291.

${ }^{60}$ Billings 294.

61 James G. Burrow, A.M.A., Voice of American Medicine (Baltimore: Johns Hopkins University Press, 1963) 10-11; Martin Kaufman, "American Medical Education," in The 
Education of American Physicians, ed. Ronald L. Nujbers (Berkeley: University of California Press, 1980) 11. Both quoted in Shortt, 53.

62 See Peter Stallybrass and Allon White, TM Politics and Poetics of Transgression (Ithaca, N.Y.: Cornell University Press, 1986).

${ }^{63}$ Sigmund Freud, Totem and Taboo. Some Points of Agreement Between the Mental Lives of Savages and Neurotics, trans. James Strachey (New York: W.W. Norton, 1950) 39.

${ }^{64}$ D. Hayes Agnew, "The Medical History of the Philadelphia Almshouse," History of Blockley ... from its Inception, 1711-1928, comp. John Welsh Croskey (Philadelphia: F.A. Davis Company, 1929) 62. Presenting a history of the Almshouse as a, preliminary to his clinical surgery course, Agnew (1818-1892) observed to an audience of future physicians, "it is a shocking thing, gentlemen, to cut up dead people; and one might suppose from the horror with which some people shun you, that students were in the habit of eating them" (35). Agnew stripped his cadavers of flesh by placing them in a pond of full eels. The pond was also the source of eels for a merchant with a reputation for selling the best eels in town until the secret of their nourishment became known and Agnew's reputation suffered. Thomas Eakin's group portrait, The Agnew Clinic, was based on an 1886 photograph, perhaps taken by Eadweard Muybridge. The portrait was cleansed of bloody hands and gowns at Agnew's request.

65 Like residual tales of Nazi doctors, this persistent construction of the poor has resurfaced in a recent furor over a Milwaukee politician's proposal to sell the organs of dead welfare recipients to reduce county burial expenses and remedy a shortage of organ donors. The politician, a member of the County Board of Supervisors, argued, "If they can't help society while they're alive, maybe they can help it while they're dead." ("Furor Over Call to Sell Organs of Poor People," New York Times, 21 July 1990.) His remarks parallel arguments in the grave-robbing debate around the Philadelphia Almshouse in 1845 , cited by protesting Board members: " $\{A]$ s paupers are of no use to society while living, there is no wrong done in making them useful when dead" (quoted in Lawrence, 160) See how this trope appears in the testimony of Francois de Sales (1567-1622), a saint of the Counter-Reformation: "I wish really for only one thing, that when I have expired, you shall deliver my body over to the doctors to perform the anatomy of it; it will be a relief to me to know that at least I shall serve the public in some way being dead, since I have been of no service during my life" (quoted in Ferrari, 102)

${ }^{66}$ See Percy Fitzgerald, Chronicles of Bow Street Police-Office (London: Chapman \& Hall, 1888; Montclair, N.J.: Patterson Smith, 1972), vol. 2, 186-221.

${ }^{67}$ Diary, Vol. 1, No. 5, May 10, 182. For other descriptions of the famous amphitheater, see Oliver Impey and Arthur MacGregor, eds., The Origins of Museums. The Cabinet of 
Curiosities in Sixteenth- and Seventeenth Century Europe (Oxford: Oxford, Clarendon Press, 1985) 119-120, and William S. Heckscher, Rembrandt's' Anatomy of Dr. Nicolaas Tulp (Washington Square: New York University Press, 1958) 110-116.

68 See Heckscher, 85-109, and an extract, 182-183, quoted from A. Benedetti, Historia corporis humani, for a contemporary discussion of public and especially punitive anatomies.

${ }^{69}$ Karp 163-164.

${ }^{70}$ Ferrari, 50-51. According to Barker, visitors to the seventeenth-century public anatomy in Amsterdam would have included both Rembrandt, who recorded it in The Anatomy Lesson of Dr. Nicolaas Tulp and Descartes, the philosopher of a disembodied subjectivity (The Tremulous Private Body, 115.)

${ }^{71}$ Francis Barker relates this to "bourgeois naturalism, which has nothing to do with nature, and everything to do with naturalizing the suppression of the signs of the artefact's production." See "A Challenged Spectacle," in The Tremulous Private Body 18.

72 R. Reed, Ancient Skins, Parchments, and Leathers (London: Seminar Press) 285-288. Observers give different accounts of the softness and fineness of the grain of human leather depending on the body part and the method of tanning. It is said that color may vary from pale pink to deep brown, that the thickest skin comes from the belly and the softest from the thighs. Human skin is said to be difficult to rid of its hair. An account of the tanning process says the skin must be saturated with a strong solution of alum, roman vitriol, and table salt for several days. It is subsequently dried in a shady place and dressed. Other experts recommend sumac as a tanning medium (Thompson, 15). Paul Kersten described the skin he used to bind the Friedenthal volume: "The grain... resembled a mixture of large-grained goatskin and pigskin; the portion representing the back had the coarser grain while the breast and belly areas were smaller grained. In thickness it corresponded to morocco leather .... It had a very considerable toughness and was somewhat difficult to work to a smooth surface since the grain extended rather deeply into the skin, much as in pigskin; otherwise it felt like morocco leather, and were it not white it would be taken for such ... " (O'Malley, 447).

${ }^{73}$ It is instructive to compare the ideological tensions surrounding the invention of the public art museum during the French Revolution with those attending the anatomical school and its collections. Revolutionary and Napoleonic plunderers claimed to have seized aristocratic art for a higher purpose after its original possessors had neglected and mistreated their treasures. "If works of art are to be gathered together for the moral, cultural and esthetic benefit of the people of Paris or London or New York," Linda Nochlin observes, they must be "ripped loose from their original functions or settings to be taken away from some previous owner--either willing or not." ("Museums and Radicals: A History of Emergencies," Art in America, 59 [July-August, 1971]: 28-29). This 
is the mirror image of the debate about paupers' bodies, which physicians argued were appropriable for the sake of the universal knowledge of humankind, especially in the condition of self-neglect and abuse in which their owners had lived their lives. Popular manifestos against high art have often compared museums with lifeless cemeteries, "something pure and expensive to do with the Dead and Buried."

${ }^{74}$ This newspaper clipping was pasted into the flyleaf of the Catalogue des Sciences Medicales, one of the volumes bound by John Stockton Hough. Cf. footnote 42. Boots made from human skin were exhibited in the 1876 Centennial Exhibition in Philadelphia by the Department Of Interior near the Indian Department Exhibit. The boots, 14 inches high, were supplied by H. \& A. Mahrenholz, shoemakers in New York, City, along with boots of alligator, anaconda and boa constrictor "to show what could be made out of human skin as well as some men yet do not! Our most refined fashinable [sic] women wear the hair of dead persons on their head. Should you not feel disposed to exhibit the human Boots in the Centennial Building. As you suggested you will be kind enough to return them to us, and exhibit the other 2 Pair yet if you exhibit the human Boots also, we will donate three Pr. For Smithsonian." Correspondence between Mahrenholz and nervous Smithsonian officials reveals that the boots were made "from two male subjects old men, off the stomach or rump to the back of the bone." The story appears in four letters: H. \& A. Mahrenholz to Prof. Spencer F. Baird, Feb. 16, 1876; Mahrenholz to Baird, Mar. 16, 1876; Mahrenholz to Baird, Apr. 5, 1876; and Mahrenholz to Baird, Apr. 15, 1876. Collection of the Division of Agriculture and Natural Resources, National Museum of American History.

${ }^{75}$ More recently, stories of Ed Gein, a Wisconsin mass murderer who tanned the skin of his victims to make a variety of bizarre artifacts, appeared in newspaper articles, books, and a popular song remembered by a colleague growing up in nearby Minnesota in the 1950s. Particulars of the plot of Alfred Hitchcock's Psycho, including Norman Bates's psychological attributes, are said to have been based on the Gein murders. See Jack Levin and James Alan Fox, Mass Murder: America's Growing Menace (New York: Plenum Press, 1985) 3-7. Also Francois Truffaut, Hitchcock/Truffaut (New York: Simon and Schuster, 1967) 205. 